\title{
Selection of Experimental Hybrids of Strawberry Using Multivariate Analysis
}

Eneide Barth 1,*, Juliano Tadeu Vilela de Resende ${ }^{2,3, *}$, Aline Fabiana Paladini Moreira ${ }^{2}$, Keny Henrique Mariguele ${ }^{4}$ (D), André Ricardo Zeist ${ }^{5}$, Mayara Barbosa Silva ${ }^{6}$, Gianne Caroline Guidoni Stulzer ${ }^{2}$, João Gabriel Macedo Mafra ${ }^{2}$, Leandro Simões Azeredo Gonçalves ${ }^{2}$, , Sergio Ruffo Roberto ${ }^{2}$ (D) and Khamis Youssef $7, *(\mathbb{D})$

1 Empresa de Pesquisa Agropecuária e Extensão Rural de Santa Catarina (Epagri), Rua XV de Novembro, 525, Pomerode 89107-000, SC, Brazil

2 Department of Agronomy, Londrina State University, Rodovia Celso Garcia 12 Cid, km 380, Londrina 86051-900, PR, Brazil; fabianapaladini@gmail.com (A.F.P.M.); g.caroline.stulzer@gmail.com (G.C.G.S.); jgmafra@hotmail.com (J.G.M.M.); leandrosag@uel.br (L.S.A.G.); sroberto@uel.br (S.R.R.)

3 Department of Agronomy, Midwestern State University, Alameda Élio Antonio Dalla Vecchia, 838, Guarapuava 85040-080, PR, Brazil

4 Empresa de Pesquisa Agropecuária e Extensão Rural de Santa Catarina (Epagri), Rodovia Antônio Heil, 6800, Itajaí 88318-112, SC, Brazil; kenymariguele@epagri.sc.gov.br

$5 \quad$ University of Western Paulista, Presidente Prudente 19050-920, SP, Brazil; andre.zeist@bol.com.br

6 Department of Agronomy, Maringá State University, Av. Colombo, 5790, Maringá 87020-900, PR, Brazil; mayarabarbosa2012@gmail.com

7 Agricultural Researcher Center, Plant Pathology Research Institute, 9 Gamaa St., Giza 12619, Egypt

* Correspondence: earth@epagri.sc.gov.br (E.B.); jvresende@uel.br (J.T.V.d.R.); youssefeladawy@yahoo.com (K.Y.); Tel.: +55-47-3378-8411 (E.B.)

Received: 8 April 2020; Accepted: 17 April 2020; Published: 22 April 2020

\begin{abstract}
The selection of superior strawberry genotypes is a complex process due to the high variability after hybridization that is caused by the octoploid nature and the heterozygosis, making the selection of multiple traits difficult. This study aimed to select strawberry hybrids with the potential for fresh consumption and/or processing by applying multivariate analysis to obtain traits of interest simultaneously. Hybrids were obtained from the crossing among seven commercial cultivars, defining a selection of $10 \%$ of them. The experimental design consisted of an augmented block design, with two commercial cultivars, Camarosa and Camino Real, as the controls. Different variables, including the number and average mass of commercial fruits, total fruit mass, $\mathrm{pH}$, soluble solids (SS), titratable acidity (TA), SS/TA ratio, reducing sugars, pectin, ascorbic acid, phenolic compounds, and anthocyanin's, were assessed. The selection of hybrids was based on the Mulamba and Mock rank-summation index, principal component analysis, and Ward's hierarchical cluster analysis. The selection index was based on different weights being adopted for fresh market and processing. The assessed traits had high variability between hybrids. The highest selection gains were obtained for production traits, but the different weight assignment resulted in different classifications of hybrids for both fresh consumption and processing. Most of the hybrids selected by the index remained in the same group in the principal component and hierarchical cluster analyses, which indicates that multivariate analysis is a valuable tool for assisting in the selection of superior hybrids in the strawberry crop.
\end{abstract}

Keywords: plant breeding; hybrids; strawberry; Mulamba and Mock 


\section{Introduction}

Strawberry (Fragaria xananassa Duchesne ex Rozier) is a crop that is widely grown in the world, both for fruit market to fresh consumption and to processing, mainly due to the appearance, texture, taste, aroma, and nutritional content [1].The worldwide production of strawberry is almost 9.2 million tons with a harvested area around 395,844 ha. China is the largest producer, with 3.72 million tons in 2017, followed by the US, Mexico, Egypt, and Turkey [2].

Yield, disease/pest resistance, and fruit quality, including appearance, texture, taste, and aroma, are the main traits analyzed in strawberry breeding programs [3,4]. Strawberry fruits are relevant sources of bioactive compounds, as they have high levels of ascorbic acid, folate, and phenolic constituents that present biological activity relevant to human health [5].However, these bioactive compounds are not prioritized in breeding programs, and most of the studies are only related to germplasm characterization [6-8].

Most of the strawberry cultivars that are planted in Brazil, especially in the Mid-West and South, are imported from Chile and Argentina, which come from breeding programs of the United States, Spain, and Italy $[9,10]$. This dependence on foreign cultivars and nurseries results in high costs for growers due to expenses in importing seedlings and paying royalties. In this context, the development of strawberry breeding programs in Brazil is of high relevance for reducing the dependence on imported genotypes and developing cultivars that are more adapted to weather conditions of the Brazilian producing regions.

Genotype selection that is based on different traits, such as production, sensoric analysis, and physicochemical aspects of strawberry fruits, can be a complication for the breeder during the selection and advancement of breeding programs [11]. Thus, the use of multivariate analyses, such as nonlinear indices, principal components (PCA), and hierarchical clusters, which aim to combine information of different characteristics into a single value or graphically, has become relevant to compare and classify genotypes that are based on such a set of traits.

Based on the above mentioned overview, the objective of this study was to evaluate and select strawberry genotypes obtained from crosses, while using multivariate analysis based on yield and physicochemical traits for fresh market and processing.

\section{Materials and Methods}

\subsection{Crossbreeding and Obtaining Hybrids}

Seven commercial strawberry were used, namely 'Aromas', 'Camarosa', 'Dover','Festival Florida', 'Oso Grande', 'Sweet Charlie', and 'MilseyTudla'. Most of them are short-day cultivars, except 'Aromas', which is a day-neutral. Hybridization was performed according to Chandler et al. [3], obtaining ten seedling populations: 'Dover' $\times$ 'Aromas' (RVDA), 'Camarosa' $\times$ 'Aromas' (RVCA), 'Dover' $\times$ 'Sweet Charlie' (RVDS), 'Oso Grande' $\times$ 'Milsey Tudla' (RVOT), 'Flórida Festival' $\times$ 'Sweet Charlie' (RVFS), 'Sweet Charlie' $\times$ 'Aromas' (RVSA), 'Milsey Tudla' $\times$ 'Aromas' (RVTA), 'Milsey Tudla' $\times$ 'Sweet Charlie' (RVTS), 'Camarosa' $\times$ 'Sweet Charlie' (RVCS), and 'Flórida Festival' $\times$ 'Aromas' (RVFA).

After crossing, formation, and development of fruits, the achene's were removed, dried, acid scarified, and germinated in vitro, as described by Galvão et al. [12].The seedlings were transplanted into 72-cell polypropylene trays containing bio-stabilized pine bark substrate when they reached four to five true and expanded leaves, i.e., at 60 days after germination.

After acclimatization, 1200 plants were transplanted in the field under a low tunnel at a spacing of $0.30 \times 0.40 \mathrm{~m}$ in Federer's augmented blocks design. From this experiment, 194 genotypes were selected. The selection was made based on the agronomic and psychopathological traits outlined by Galvão et al. [12].

The genotypes were cloned to produce seedlings for use in the subsequent experiment. The stock plants selected from the 194 genotypes were kept in pots in a greenhouse. The stolons produced were cut from these plants and then transplanted in trays of 72 cells with commercial substrate. 


\subsection{Installation and Management of Experimental Units}

One hundred and ninety-four hybrids, which were pre-selected in July 2013, were transplanted to an experimental area of the Center for Research on Vegetables of the Department of Agronomy of the Midwestern Parana State University (Unicentro) located in Guarapuava, PR ( $25^{\circ} 38^{\prime}$ S and $51^{\circ} 48^{\prime} \mathrm{W}$, with an altitude of 1100 meters). The regional climate is $\mathrm{aCfb}$ (humid mesothermal subtropical), i.e., a temperate climate with a warm summer, moderate winter, and no defined dry season [13]. The soil is classified as Oxisol (Latossolo Bruno distroférricotípico, Brazilian Soil Classification System). Transplanting was performed in a tunnel system that was $0.8 \mathrm{~m}$ high in the central part and in $1.0 \mathrm{~m}$ wide $\times 0.25$ high beds, covered with black polyethylene film $120-\mu \mathrm{m}$ thick transparent polyethylene films were used to cover the tunnels. Spacing was $0.30 \times 0.40 \mathrm{~m}$, forming two rows. The design was Federer's augmented blocks, with two controls ('Camarosa' and 'Camino Real') at each block, 194 experimental F1 hybrids allocated in 10 blocks, and five plants per plot.

Bed fertilization was based on soil chemical analysis and it consisted of $1650 \mathrm{~kg} \mathrm{ha}^{-1}$ of simple superphosphate, $250 \mathrm{~kg} \mathrm{ha}^{-1}$ of potassium chloride, and $295 \mathrm{~kg} \mathrm{ha}^{-1}$ of urea. Trickle tape irrigation was carried out according to the crop water requirements. Preventive phytosanitary control was carried out by spraying the thiamethoxam insecticide and the azoxystrobin + difenoconazole fungicides, with applications every fifteen days and alternating throughout the harvest period. Harvesting took place when the fruits were ripe.

\subsection{Evaluation of Parameters}

The fruits from each plot were weighed and classified as commercial $(\geq 10 \mathrm{~g})$ and non-commercial $(<10 \mathrm{~g})$ to evaluate agronomic traits. Subsequently, the number of commercial fruits per plant (NCF), average mass of commercial fruits (AMCF, in g/fruit), mass of commercial fruits (MCF, in g/plant), and total fruit mass (TFM, in g/plant) were quantified and the average of the parcel was obtained.

The physicochemical characteristics and bioactive compounds were determined from samples of ripe strawberries stored during harvest at $-2{ }^{\circ} \mathrm{C}$. A calibrated MS Tecnopon mPA-210 bench top digital $\mathrm{pH}$ meter was used for $\mathrm{pH}$ determination, while using buffer solutions with the direct reading of homogenized and filtered pulp.

The soluble solids (SS) content was determined by direct reading on an Optech RMT bench top refractometer using homogenized and filtered pulp at ambient temperature, with values in Brix. Titratable acidity (TA) being determined by the titration method [14], with aliquots of $10 \mathrm{~g}$ of strawberry pulp plus $100 \mathrm{~mL}$ of distilled water. This solution was titrated with $0.1 \mathrm{~mol} \mathrm{~L}^{-1} \mathrm{NaOH}$ standard solution up to $\mathrm{pH}$ 8.2, which corresponds to the turning point of phenolphthalein. The results were expressed in $g$ citric acid $100 \mathrm{~g}^{-1}$ pulp. The SS/TA ratios were obtained.

The percentage of reducing sugars (RS) was determined according to the Lane-Eynon method, based on the reduction of copper by sugar-reducing group's sugar reducing groups. The solution, with $5 \mathrm{~mL}$ of homogenized strawberry pulp and $95 \mathrm{~mL}$ distilled water, was filtered through filter paper and then titrated with a burette. Subsequently, $10 \mathrm{~mL}$ of each Fehling's A and B solution and $20 \mathrm{~mL}$ of distilled water were added to the Erlenmeyer flask and then heated to boiling. Titration was performed until the heated solution turned from blue to colorless, with $\mathrm{Cu}_{2} \mathrm{O}$ residue at the bottom of the flask (brick red color) [15].

Phenolic compounds (PC) were obtained while using the Folin-Ciocalteu spectrophotometric method, according to Bucic-Kojic et al. [16]. A 5-mL sample of strawberry pulp was homogenized with $50 \mathrm{~mL}$ of $50 \%$ ethanol in a mixer for $2 \mathrm{~min}$ and then centrifuged for five minutes. Of the centrifuged sample, it was taken $0.2 \mathrm{~mL}$ aliquot and transferred to a test tube to which $1.8 \mathrm{~mL}$ distilled water, $10 \mathrm{~mL}$ of 10-fold diluted Folin-Ciocalteau reagent. After 30 seconds to $8 \mathrm{~min}, 8 \mathrm{~mL} \mathrm{7.5 \%} \mathrm{sodium} \mathrm{carbonate}$ solution $\left(\mathrm{Na}_{2} \mathrm{CO}_{3}\right)$ was added. The test tube was stirred and left to stand in the dark for two hours. Reading was performed in a spectrophotometer at $765 \mathrm{~nm}$, using a mixture of all reagents plus $1.8 \mathrm{~mL}$ distilled water as blank, but without an aliquot of the centrifuged sample. Gallic acid was used as a standard. The results were expressed as mg gallic acid equivalent (GAE) $100 \mathrm{~g}^{-1}$ pulp. 
The total pectin (TP) was extracted with 95\% ethyl alcohol, according to the method that was adapted by McCready and McComb [17], and colorimetrically determined while using the carbazole reaction, according to the methodology that was described by Bitter and Muir [18]. The amount of Total Pectin was expressed as g total pectin $100 \mathrm{~g}^{-1}$ pulp.

The ascorbic acid (AA) content was determined by the standard AOAC [19] titration method that was modified by Youssef and Hussien [20]. A $25 \mathrm{~g}$ aliquot of strawberry pulp was taken and then added to $50 \mathrm{~g}$ of $2 \%$ oxalic acid. From this solution, $20 \mathrm{~g}$ were transferred into volumetric flask and filled it up with oxalic acid $(2 \%)$ until a volume of $50 \mathrm{~mL}$. Subsequently, the solution was filtered through filter paper and a $10 \mathrm{~mL}$ aliquot was taken for titration with standardized DCFI (2,6-dichlorophenol-indophenol). The results were expressed as $\mathrm{mg}$ ascorbic acid $100 \mathrm{~g}^{-1}$ pulp.

The anthocyanin (ANT) content was determined by the $\mathrm{pH}$ differential method that was described by Giusti and Wrosltad [21], with adaptations for strawberry. This method is based on two buffer systems ( $0.025 \mathrm{M}$ potassium chloride at $\mathrm{pH} 1.0$ and $0.4 \mathrm{M}$ sodium acetate at $\mathrm{pH} 4.5)$, in which a $0.3 \mathrm{~mL}$ aliquot of the hydroalcoholic extract was pipetted and then added to $2.7 \mathrm{~mL}$ of the buffer solutions separately. The samples were analyzed at 496 and $700 \mathrm{~nm}$ using a spectrophotometer (Cary 60-Agilent Technologies). The difference in absorbance $(\triangle \mathrm{A})$ between buffer systems was calculated while using the equation $\Delta \mathrm{A}(\mathrm{A} \lambda-\mathrm{A} 700 \mathrm{~nm}) \mathrm{pH} 1.0-(\mathrm{A} \lambda-\mathrm{A} \lambda 700 \mathrm{~nm}) \mathrm{pH} 4.5$.

The concentration of anthocyanin pigments was determined based on extract volume and sample mass [22], according to the equation $A t=(\Delta \mathrm{A} \times \mathrm{MW} \times \mathrm{f} \times 100) \varepsilon \times 1$, where At is the anthocyanin being expressed in mg pelargonidin-3-glycoside $100 \mathrm{~g}^{-1}$ pulp, $\Delta \mathrm{A}$ is the difference of absorbance (ApH $1.0-$ $\mathrm{ApH} 4.5), \mathrm{MW}$ is the pelargonidin-3-glycoside molecular weight (433.3), $\mathrm{f}$ is the dilution factor, and $\varepsilon$ is the molar absorptivity coefficient (27300).

\subsection{Statistical Analysis}

The data were subjected to analysis of variance (ANOVA), using the packages Agricolae v.1.3-1 [23] on $\mathrm{R}$ (http://cran-r.c3sl.ufpr.br), the percentage values of reducing-sugars were arcsine-square root transformed to normalize variance. Data dispersion in each population was assessed using RcmdrPlugin.KMggplot2 v.0.2-6 [24] on R. The agronomic, physicochemical, and biochemical traits were analyzed by Pearson correlation analysis using Corrplot v.0.84 [25] on R. The hybrid selection, by the statistical software Genes [26], was based on the rank-summation index [27], from which heritability and gain with selection was estimated. The weights that were established by [28] for fresh market and processing were adopted for the selection index (Table 1). Principal component analysis using FactoMineR v.2.2 [29] on RandWard's hierarchical cluster analysis by Agricolae v.1.3-1 [23] on R, using the standardized mean Euclidean distance. 
Table 1. Weights to Mulamba and Mock selection index in Fragaria $\times$ ananassa Duchesne ex Rozierfor the traits:number of commercial fruits (NCF), average mass of commercial fruits (AMCF, in $\mathrm{g} /$ fruit), mass of commercial fruits (MCF, in g/plant), total fruit mass (TFM, in g/plant), soluble solids (SS, in brix), titratable acidity (TA, in g citric acid $100 \mathrm{~g}^{-1} \mathrm{pulp}$ ), soluble solids/titratable acidity (SS/TA ratio), reducing sugar (RS, in \%), phenolic compounds (PC, in mg galic acid $100 \mathrm{~g}^{-1}$ pulp), total pectin (TP, in $\mathrm{g}$ total pectin $100 \mathrm{~g}^{-1}$ pulp), ascorbic acid (AA, in mg ascorbic acid $100 \mathrm{~g}^{-1}$ pulp) and anthocyanins (ANT, in mg pelargonidin-3-glycoside $100 \mathrm{~g}^{-1}$ pulp).

\begin{tabular}{ccc}
\hline Traits & \multicolumn{2}{c}{ Weights } \\
\cline { 2 - 3 } & Fresh Consumption & Processing \\
\hline Number of Commercial Fruits (NCF) & 5 & 2 \\
Average Mass of Commercial Fruits (AMCF) & 5 & 1 \\
Mass of Commercial Fruits (MCF) & 5 & 2 \\
Total Fruit Mass (TFM) & 3 & 4 \\
Ph & 3 & 5 \\
Soluble Solids (SS) & 4 & 5 \\
Titratable Acidity (TA) & 4 & 5 \\
Reducing Sugar (RS) & 5 & 2 \\
Phenolic Compounds (PC) & 5 & 2 \\
Total Pectin (TP) & 5 & 5 \\
Ascorbic Acid (AA) & 3 & 1 \\
Anthocyanins(ANT) & 5 & 5 \\
\hline
\end{tabular}

\section{Results}

\subsection{Boxplot Analysis}

The genotypic differences were significant for the number of commercial fruits (NCF), mass of commercial fruit (MCF), total fruit mass (TFM), SS/TA ratio, total pectin (TP), ascorbic acid (AA), and anthocyanins (ANT). The genotypesof the populations from crossing 'Camarosa' $\times$ 'Aromas' and 'Camarosa' $\times$ 'Sweet Charlie' had higher means than those that were observed in the controls for NCF, MCF, and TFM (Figure 1). Although the genotypes of the other populations did not stand out with regard to these traits; almost all of them contained individuals with higher means than the control. All of the populations only showed low values for the average mass of commercial fruits (AMCF) when compared to the controls. However, superior hybrids were observed for crossing 'Dover' $\times$ 'Aromas' and 'MilseyTudla' $\times$ 'Aromas' (Figure 1).

The genotypes of populations also presented variation regarding physicochemical traits. When compared to the controls, all of the hybrids from crossing 'Camarosa' $\times$ 'Sweet Charlie' had higher $\mathrm{pH}$ and $\mathrm{RS}$ values (Figures 2 and 3), while all hybrids from crossing 'Camarosa' $\times$ 'Aromas' had higher TA and PC values (Figures 2 and 3).The crossings 'Sweet Charlie' $\times$ 'Aromas', 'Dover' $\times$ 'Sweet Charlie', and 'Milsey Tudla' $\times$ 'Aromas' also showed high means for TA and PC. However, all of the hybrids from the population 'Camarosa' $\times$ 'Aromas' presented lower values of TP than the controls, while those from 'Dover' $\times$ 'Aromas' had a high mean. Several outliers were observed from other crossings (Figure 3).

Most genotypes from crossings 'Camarosa' $\times$ 'Aromas' and 'Camarosa' $\times$ 'Sweet Charlie' were superior to the controls for the SS and SS/TA ratio (Figure 2).The genotypes of populations 'Camarosa' $\times$ 'Aromas' and 'Milsey Tudla' $\times$ 'Aromas' stood out for ANT (Figure 3). Most of the hybrids presented low means for AA when compared to the controls, except 'Festival Florida' $\times$ 'Aromas', for which the mean and most individuals were superior (Figure 3). 

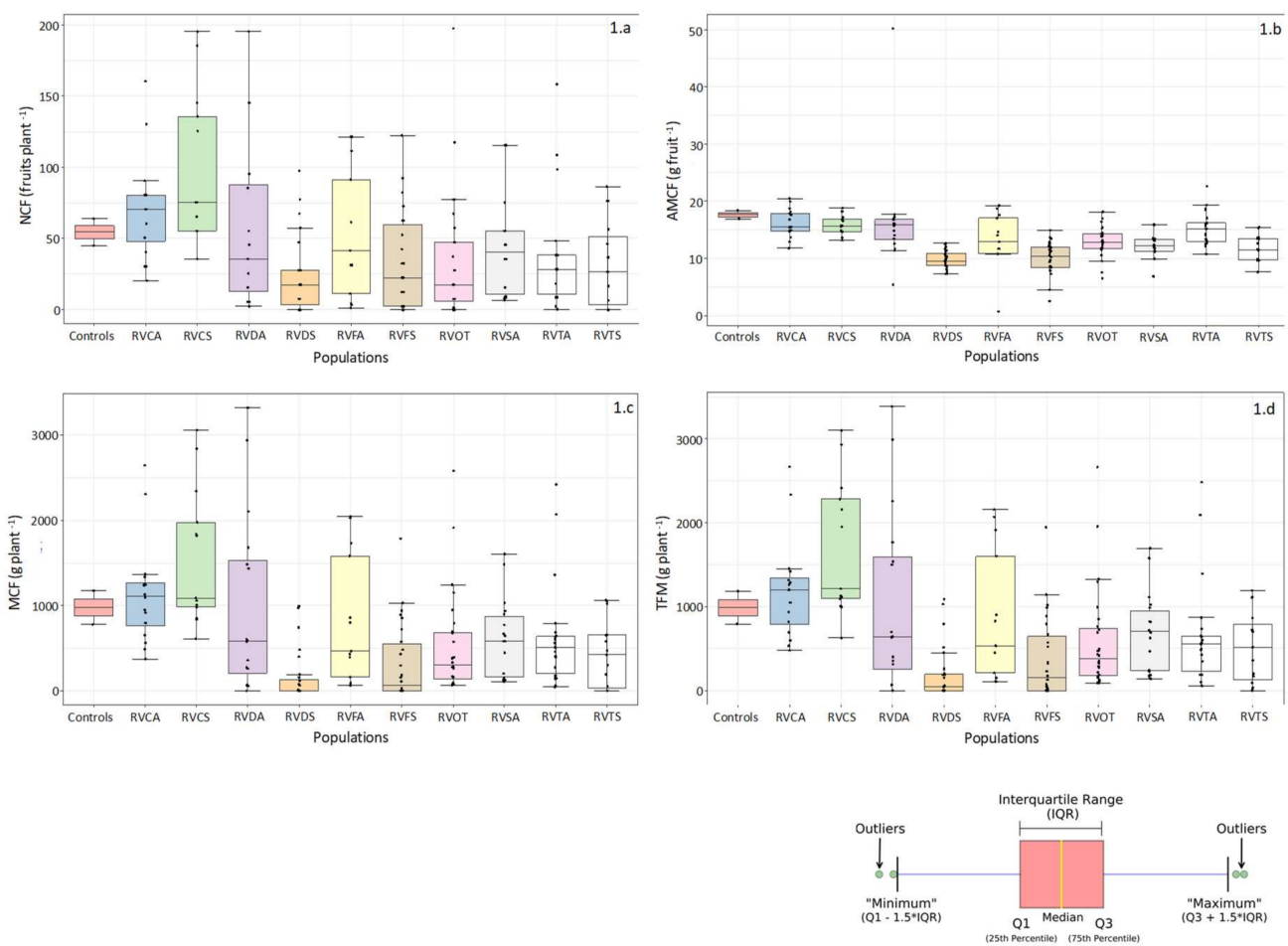

Figure 1. Analysis for (a) Number of Commercial Fruits (NCF, fruits/plant), (b) Average Mass of Commercial Fruits (AMCF, g/fruit), (c) Mass of Commercial Fruits (MCF, g/plant), and (d) Total Fruit Mass (TFM, g/plant) for genotypes of population evaluated.
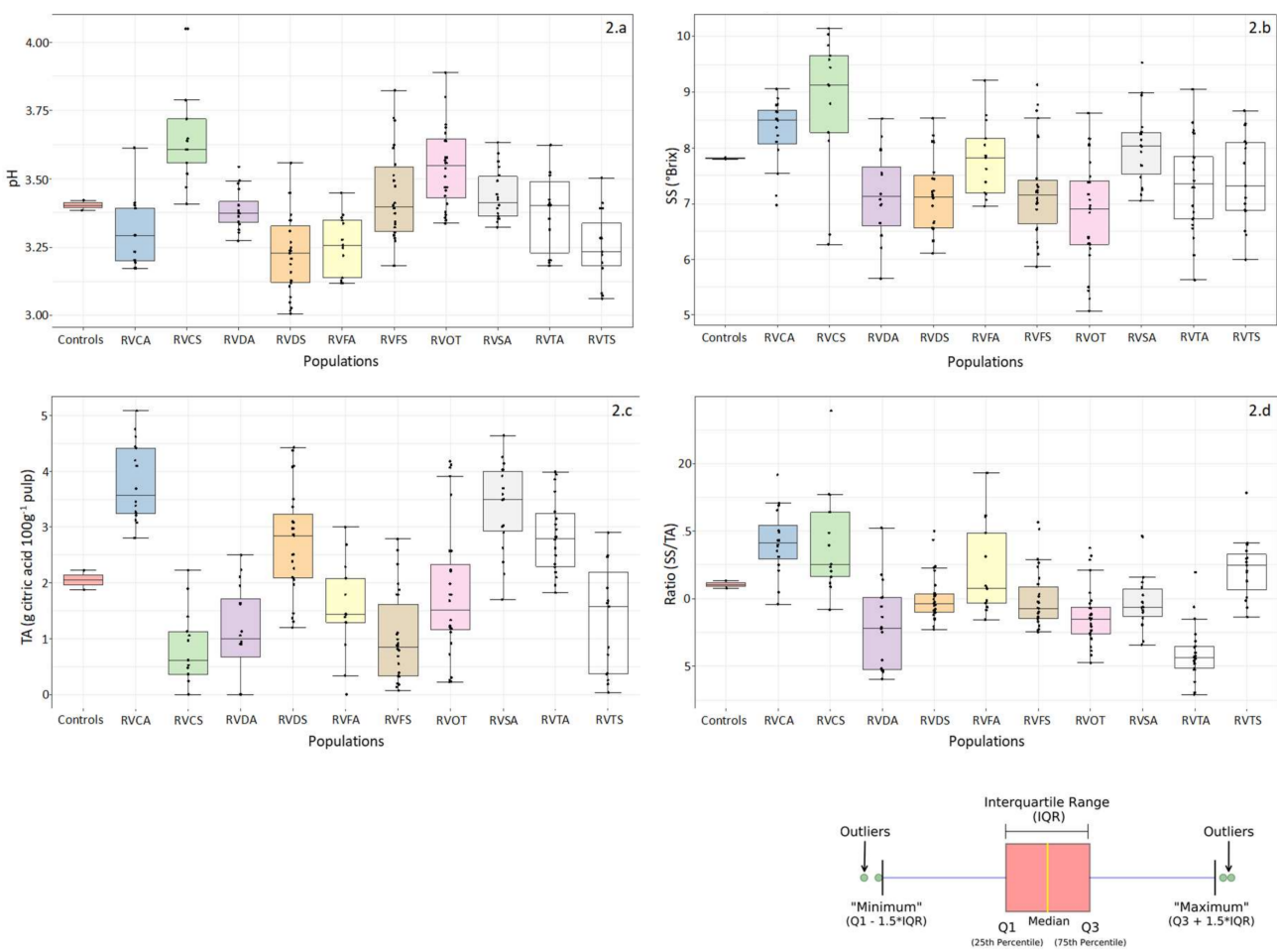

Figure 2. Boxplot analysis for (a) pH, (b) Soluble Solids (SS, Brix), (c) Titratable Acidity (TA, g citric acid $100 \mathrm{~g}^{-1}$ pulp), and (d) SS/TA ratio: Soluble Solids/Titratable Acidity for genotypes of population evaluated. 

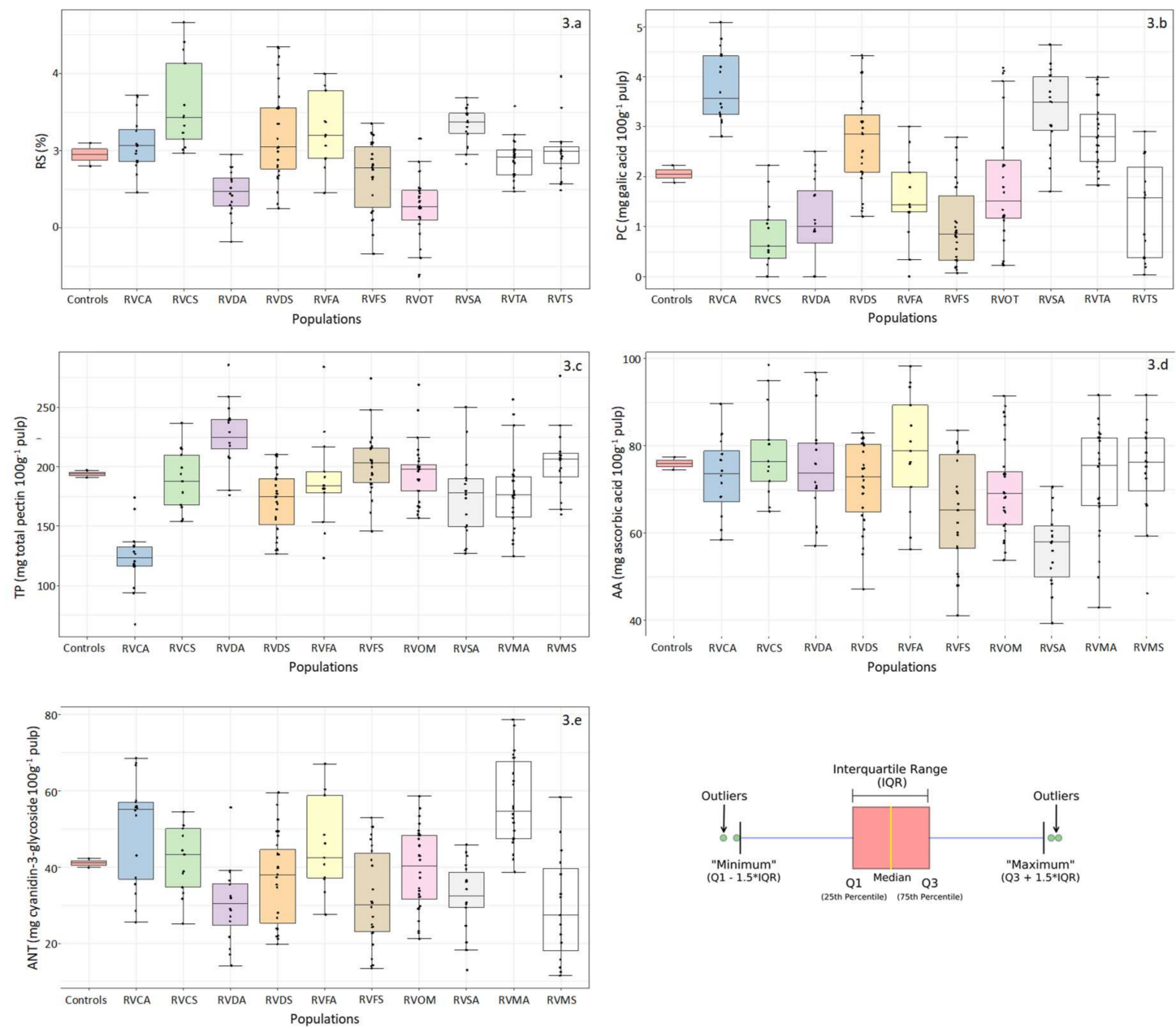

Figure 3. (a) Boxplot analysis for Reducing Sugar (RS, \%), (b) Phenolic Compounds (PC, mg galic acid $100 \mathrm{~g}^{-1}$ pulp), (c) Total Pectin (TP, g total pectin $100 \mathrm{~g}^{-1}$ pulp), (d) Ascorbic Acid (AA, mg ascorbic acid $100 \mathrm{~g}^{-1}$ pulp), and (e) Anthocyanins (ANT, mg pelargonidin-3-glycoside $100 \mathrm{~g}^{-1}$ pulp)for genotypes of population evaluated.

\subsection{Pearson Correlation}

The agronomic traits presented the highest positive correlations (Figure 4), ranging from 0.61 to 1.00. Among the physicochemical attributes, the SS/TA ratio presented negative and high correlation with TA $(-0.88)$ and positive correlation with SS (0.56). The other postharvest traits were not correlated with yield traits, except for the SS and SS/TA ratio, which were positively correlated with NCF, MCF, and TFM. 


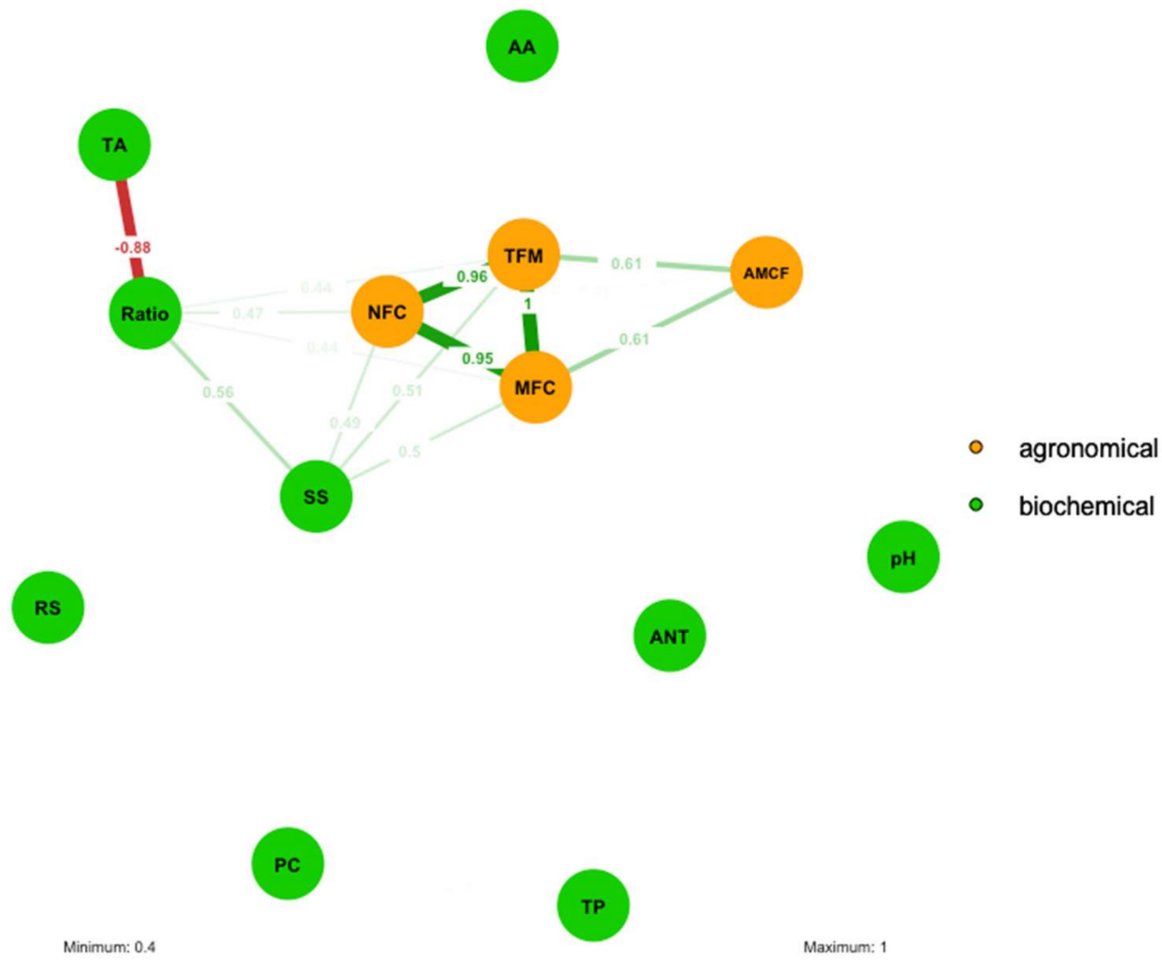

Figure 4. Correlation analysis between agronomic, physicochemical, and bioactive compound traits obtained from different Fragaria $\times$ ananassa Duschesne ex Roziergenotypes.NCF: Number of Commercial Fruits (fruits/plant), AMCF: Average Mass of Commercial Fruits (g/fruit), MCF: Mass of Commercial Fruits (g/plant), TFM: Total Fruit Mass (g/plant), SS: Soluble Solids (Brix), TA: Titratable acidity (g citric acid $100 \mathrm{~g}^{-1}$ pulp), SS/TA Ratio: Soluble Solids/Titratable Acidity, RS: Reducing Sugar (\%), PC: Phenolic Compounds (mg galic acid $100 \mathrm{~g}^{-1}$ pulp), TP: Total Pectin (g total pectin $100 \mathrm{~g}^{-1}$ pulp), AA: Ascorbic Acid (mg ascorbic acid $100 \mathrm{~g}^{-1}$ pulp), and ANT: Anthocyanins (mg pelargonidin-3-glycoside $100 \mathrm{~g}^{-1}$ pulp).

\subsection{Hybridization Gains and Selection Rank}

Among the yield traits, heritability ranged from 53.84 (AMFC) to 93.48\% (NCF). For physicochemical attributes, the lowest and highest heritability were presented for SS (47.02\%) and ANT (93.73\%), respectively. The other postharvest traits had a variation that ranged between $60.57-87.87 \%$ (Table 2).The highest selection gains with the application of the Mulamba and Mock [27] index were obtained for traits that were related to yield (Table 2). 
Table 2. Heritability estimation $\left(\mathrm{h}^{2}\right)$, mean of all hybrids $\left(\mathrm{Xo}_{\mathrm{o}}\right)$, mean of selected clones $(\mathrm{Xs})$, selection gain (SG), and percentage of selection gain (SG\%) for traits analyzed in Fragaria $\times$ ananassa Duchesne ex Rozier hybrids obtained by the Mulamba and Mock [27] selection index, with economic weights determined for the selection for fruit production for fresh consumption and processing.

\begin{tabular}{ccccccccc}
\hline \multirow{2}{*}{ Traits } & \multirow{2}{*}{$\mathbf{h}^{2} \mathbf{\%}$} & $\mathbf{X}$ & \multicolumn{3}{c}{ Fresh Consumption } & \multicolumn{3}{c}{ Processing } \\
\cline { 5 - 9 } & & & $\mathbf{X s}$ & SG & SG \% & Xs & SG & SG \% \\
\hline NCF & 93.49 & 43.60 & 121.45 & 72.75 & 166.69 & 100.20 & 52.88 & 121.17 \\
AMFC & 53.84 & 13.01 & 16.86 & 2.07 & 15.95 & 16.04 & 1.63 & 12.55 \\
MCF & 87.59 & 615.34 & 1955.94 & 1174.21 & 190.82 & 1563.21 & 830.22 & 134.92 \\
TFM & 87.72 & 687.00 & 2035.51 & 1182.93 & 172.19 & 1659.12 & 852.75 & 124.13 \\
pH & 60.93 & 3.39 & 3.44 & 0.03 & 0.84 & 3.55 & 0.10 & 2.90 \\
SS & 47.02 & 7.50 & 8.69 & 0.56 & 7.44 & 8.75 & 0.59 & 7.82 \\
TA & 75.12 & 0.78 & 0.66 & -0.09 & -11.52 & 0.80 & 0.02 & 2.25 \\
SS/TA Ratio & 82.91 & 10.15 & 13.64 & 2.90 & 28.57 & 11.61 & 1.21 & 11.92 \\
RS & 60.57 & 2.92 & 3.32 & 0.24 & 8.26 & 3.48 & 0.34 & 11.62 \\
PC & 73.82 & 185.48 & 195.50 & 7.39 & 3.99 & 188.14 & 1.96 & 1.06 \\
TP & 87.87 & 2.07 & 1.80 & -0.24 & -11.52 & 2.17 & 0.09 & 4.29 \\
AA & 84.64 & 70.36 & 85.27 & 12.62 & 17.93 & 76.36 & 5.08 & 7.21 \\
ANT & 93.73 & 39.36 & 52.24 & 12.06 & 30.65 & 51.41 & 11.29 & 28.68 \\
\hline
\end{tabular}

NCF: Number of Commercial Fruits (fruits/plant), AMCF: Average Mass of Commercial Fruits ( $\mathrm{g}$ fruit $\left.{ }^{-1}\right)$, MCF: Mass of Commercial Fruits (g/plant), TFM: Total Fruit Mass (g/plant), SS: Soluble Solids (Brix), TA: Titratable acidity (g citric acid $100 \mathrm{~g}^{-1}$ pulp), SS/TA Ratio: Soluble Solids/ Titratable Acidity, RS: Reducing Sugar (\%), PC: Phenolic Compounds (mg galic acid $100 \mathrm{~g}^{-1}$ pulp), TP: Total Pectin (g total pectin $100 \mathrm{~g}^{-1}$ pulp), AA: Ascorbic Acid (mg ascorbic acid $100 \mathrm{~g}^{-1}$ pulp) and ANT: Anthocyanins (mg pelargonidin-3-glycoside $100 \mathrm{~g}^{-1}$ pulp).

However, the different economic weights that were assigned to each trait resulted in different gains between selections for fresh consumption and processing. The same results were observed for the SS/TA ratio, PC, and AA, for which the highest weight assigned in the selection for fresh consumption resulted in gains of $28.57,3.99$, and $17.93 \%$, respectively, while the selection for processing had gains of $11.92,1.06$, and $7.21 \%$, respectively.

High weights were applied for $\mathrm{pH}$ and SS in the selection for processing, which resulted in high gains for both traits (2.90 and 7.82\%, respectively) when compared to the selection for fresh consumption ( 0.84 and $7.44 \%$, respectively). The same weight was stipulated for ANT in both types of selection, but the highest gain was obtained for fresh consumption $(30.65 \%)$. The gain for TA and TP for fresh consumption was negative $(-11.52 \%)$, but it was positive when a high weight was applied to the selection index for processing (2.25 and $4.29 \%$, respectively). RS was the only variable with the lowest gain when the highest weight was assigned, with $8.26 \%$ for fresh consumption and $11.64 \%$ for processing.

Among a total of 194 hybrids, $10 \%$ were selected, which resulted in 28 hybrids, among which ten were selected for their dual aptitude, i.e., they were simultaneously selected for fresh consumption and processing. The ten selected hybrids were RVCS10, RVCS04, RVCS09, RVCS11, RVCS07, RVCA06, RVCA14, RVTA12, RVTA09, and RVSA14. Crossings in which 'Camarosa' and 'Aromas' are female and male parents, respectively, resulted in the highest number of selected hybrids. The most notable crossing was 'Camarosa' $\times$ 'Sweet Charlie', whose hybrids RVCS10, RVCS04, RVCS09, and RVCS11 alternated in the first four positions for both selection types (Table 3). 
Table 3. Crossings, rank order, and adjusted means for Fragaria $\times$ ananassa Duchesne ex Rozier hybrids selected in the first ten positions based on the Mulamba and Mock [27] selection index, with economic weights established for the selection for fruit production for fresh consumption and processing.

\begin{tabular}{|c|c|c|c|c|c|c|c|c|c|c|c|c|c|c|c|c|c|}
\hline & \multirow[b]{2}{*}{ Crossings } & \multirow[b]{2}{*}{ Hybrids } & \multicolumn{2}{|c|}{ Rank Order } & \multirow[b]{2}{*}{ NCF * } & \multirow[b]{2}{*}{ AMFC } & \multirow[b]{2}{*}{ MCF } & \multirow[b]{2}{*}{ TFM } & \multirow[b]{2}{*}{$\mathrm{pH}$} & \multirow[b]{2}{*}{ SS } & \multirow[b]{2}{*}{ TA } & \multirow[b]{2}{*}{$\begin{array}{l}\text { SS/TA } \\
\text { Ratio }\end{array}$} & \multirow[b]{2}{*}{ RS } & \multirow[b]{2}{*}{ PC } & \multirow[b]{2}{*}{ TP } & \multirow[b]{2}{*}{ AA } & \multirow[b]{2}{*}{ ANT } \\
\hline & & & $\begin{array}{c}\text { Fresh } \\
\text { Consumption }\end{array}$ & Processing & & & & & & & & & & & & & \\
\hline 1 & 'Camarosa' × 'Sweet Charlie' & RVCS10 & 1 & 3 & 195 & 17 & 3056 & 3100 & 3.72 & 10.04 & 0.48 & 23.91 & 4.13 & 188.01 & -0.18 & 98.54 & 54.48 \\
\hline 2 & 'Camarosa' X'Sweet Charlie' & RVCS04 & 2 & 1 & 185 & 17 & 2837 & 2931 & 3.79 & 9.84 & 0.60 & 17.71 & 4.31 & 236.90 & 0.37 & 80.40 & 50.99 \\
\hline 3 & 'Camarosa' X 'Sweet Charlie' & RVCS09 & 4 & 4 & 145 & 14 & 1834 & 2160 & 4.05 & 9.44 & 0.58 & 17.76 & 4.41 & 215.12 & 0.53 & 90.63 & 48.19 \\
\hline 4 & 'Camarosa' X'Sweet Charlie' & RVCS11 & 3 & 2 & 125 & 16 & 1819 & 1951 & 3.65 & 10.14 & 0.66 & 16.40 & 4.66 & 210.21 & -0.07 & 94.96 & 50.14 \\
\hline 5 & 'Camarosa' X'Sweet Charlie' & RVCS07 & 7 & 9 & 135 & 19 & 2339 & 2416 & 3.41 & 9.65 & 0.89 & 10.90 & 3.45 & 168.01 & 0.97 & 80.31 & 38.86 \\
\hline 6 & 'Camarosa' X'Sweet Charlie' & RVCS01 & - & 12 & 135 & 16 & 1977 & 2286 & 3.61 & 8.12 & 0.70 & 12.03 & 3.23 & 155.63 & 1.90 & 74.21 & 50.99 \\
\hline 7 & 'Camarosa' X'Sweet Charlie' & RVCS13 & - & 10 & 55 & 15 & 846 & 1010 & 4.05 & 9.13 & 0.83 & 11.15 & 3.59 & 193.88 & 2.23 & 65.86 & 31.63 \\
\hline 8 & 'Camarosa' X'Aromas' & RVCA06 & 14 & 15 & 160 & 17 & 2646 & 2670 & 3.19 & 8.53 & 0.59 & 14.32 & 3.06 & 173.97 & 3.46 & 58.55 & 68.58 \\
\hline 9 & 'Camarosa' X'Aromas' & RVCA16 & 8 & - & 130 & 18 & 2309 & 2334 & 3.23 & 8.51 & 0.56 & 14.91 & 2.85 & 133.74 & 4.10 & 82.78 & 55.48 \\
\hline 10 & 'Camarosa' X'Aromas' & RVCA14 & 10 & 7 & 70 & 18 & 1237 & 1283 & 3.39 & 8.64 & 0.64 & 13.56 & 3.00 & 126.84 & 4.76 & 81.00 & 66.68 \\
\hline 11 & 'MilseyTudla' × 'Aromas' & RVTA16 & - & 8 & 158 & 16 & 2417 & 2482 & 3.40 & 6.73 & 0.97 & 5.20 & 3.21 & 156.91 & 3.63 & 67.81 & 77.17 \\
\hline 12 & 'MilseyTudla' × 'Aromas' & RVTA12 & 12 & 14 & 108 & 19 & 2069 & 2095 & 3.35 & 7.80 & 1.03 & 5.75 & 2.96 & 188.30 & 2.28 & 82.73 & 47.42 \\
\hline 13 & 'MilseyTudla' × 'Aromas' & RVTA09 & 18 & 5 & 28 & 23 & 681 & 733 & 3.51 & 8.50 & 1.13 & 5.40 & 3.11 & 179.40 & 2.10 & 81.80 & 70.60 \\
\hline 14 & 'MilseyTudla' × 'Aromas' & RVTA20 & 16 & - & 98 & 14 & 1359 & 1392 & 3.19 & 8.26 & 0.73 & 11.96 & 3.00 & 135.00 & 3.86 & 86.24 & 61.70 \\
\hline 15 & 'MilseyTudla' × 'Aromas' & RVTA07 & - & 13 & 28 & 15 & 457 & 491 & 3.62 & 8.27 & 1.03 & 6.41 & 3.13 & 165.75 & 2.49 & 66.11 & 53.88 \\
\hline 16 & 'MilseyTudla' X 'Aromas' & RVTA05 & - & 19 & 8 & 14 & 158 & 185 & 3.51 & 9.05 & 1.17 & 5.77 & 2.86 & 188.16 & 2.33 & 81.84 & 78.68 \\
\hline 17 & 'Sweet Charlie' X 'Aromas' & RVSA14 & 20 & 17 & 115 & 14 & 1601 & 1693 & 3.44 & 7.68 & 0.68 & 11.60 & 3.25 & 229.33 & 2.90 & 68.05 & 43.90 \\
\hline 18 & 'Sweet Charlie' X 'Aromas' & RVSA15 & - & 6 & 55 & 16 & 900 & 992 & 3.51 & 8.25 & 0.87 & 9.75 & 3.60 & 190.68 & 3.01 & 60.48 & 45.89 \\
\hline 19 & 'Sweet Charlie' X 'Aromas' & RVSA12 & - & 11 & 75 & 13 & 1027 & 1116 & 3.73 & 8.95 & 0.82 & 11.23 & 3.37 & 179.92 & 4.03 & 45.23 & 42.88 \\
\hline 20 & 'Sweet Charlie' X 'Aromas' & RVSA06 & - & 18 & 45 & 13 & 641 & 716 & 3.59 & 9.53 & 1.01 & 9.72 & 3.55 & 188.80 & 1.70 & 70.48 & 30.30 \\
\hline 21 & 'Flórida Festival' × 'Aromas' & RVFA16 & 5 & - & 91 & 18 & 1579 & 1600 & 3.37 & 9.21 & 0.46 & 16.09 & 3.20 & 184.44 & 0.33 & 98.24 & 58.96 \\
\hline 22 & 'Flórida Festival' × 'Aromas' & RVFA04 & 13 & - & 111 & 19 & 2045 & 2156 & 3.28 & 7.62 & 0.50 & 13.15 & 2.90 & 284.31 & 3.00 & 94.48 & 40.71 \\
\hline 23 & 'Flórida Festival' × 'Aromas' & RVFA14 & 15 & - & 121 & 15 & 1731 & 1916 & 3.12 & 8.60 & 0.29 & 19.31 & 3.06 & 229.61 & -0.17 & 89.34 & 58.83 \\
\hline 24 & 'Flórida Festival' × 'Aromas' & RVFA02 & 17 & - & 121 & 17 & 2029 & 2068 & 3.12 & 8.50 & 0.47 & 14.87 & 3.38 & 123.30 & 0.89 & 81.00 & 67.08 \\
\hline 25 & 'Dover' $\times$ 'Aromas' & RVDA01 & 11 & 20 & 95 & 18 & 1678 & 1766 & 3.40 & 8.21 & 0.84 & 9.44 & 2.79 & 217.51 & 2.51 & 95.11 & 38.69 \\
\hline 26 & 'Dover' x 'Aromas' & RVDA04 & 19 & - & 195 & 16 & 3371 & 3385 & 3.73 & 7.96 & 0.91 & 7.93 & 2.42 & 229.30 & 1.64 & 96.78 & 31.82 \\
\hline 27 & 'MilseyTudla' $\times$ 'Sweet Charlie' & RVTS08 & 9 & 16 & 76 & 13 & 1044 & 1105 & 3.50 & 8.43 & 0.58 & 14.14 & 3.97 & 209.43 & 2.47 & 82.99 & 38.12 \\
\hline 28 & 'Oso Grande' X 'MilseyTudla' & RVOT21 & 6 & - & 117 & 17 & 1910 & 1954 & 3.70 & 8.16 & 0.61 & 13.76 & 2.48 & 247.32 & 0.23 & 81.40 & 53.44 \\
\hline
\end{tabular}

* Adjusted means and statistically higher than controls 'Camarosa' and 'Camino Real' by Dunnett test ( $p<0.05)$. NCF: Number of Commercial Fruits (fruits/plant), AMCF: Average Mass of Commercial Fruits (g/fruit), MCF: Mass of Commercial Fruits (g/plant), TFM: Total Fruit Mass (g/plant), SS: Soluble Solids (Brix), TA: Titratable acidity (g citric acid 100 g ${ }^{-1}$ pulp), SS/TA Ratio: Soluble Solids/ Titratable Acidity, RS: Reducing Sugar (\%), PC: Phenolic Compounds (mg galic acid $100 \mathrm{~g}^{-1}$ pulp), TP: Total Pectin (g total pectin $100 \mathrm{~g}^{-1}$ pulp), AA: Ascorbic Acid (mg ascorbic acid $100 \mathrm{~g}^{-1}$ pulp) and ANT: Anthocyanins (mg pelargonidin-3-glycoside $100 \mathrm{~g}^{-1}$ pulp). 
The best hybrid selected for fresh consumption was RVCS10, which showed higher values for yield traits NCF, AMCF, and TFM, with values of 195 fruits/plant, $17 \mathrm{~g}$, and $3100 \mathrm{~g} /$ plant, respectively. Moreover, this hybrid stood out among all others for its high values ofSS/TA ratio (23.91) and AA (98.54 mg ascorbic acid $100 \mathrm{~g}^{-1}$ pulp). However, it was the third-best genotype for processing.

The genotype RVCS04 also showed high values for yield traits NCF, AMCF, MCF, and TFM, with values of 185 fruits/plant, $17 \mathrm{~g}, 2837 \mathrm{~g} /$ plant, and $2931 \mathrm{~g} /$ plant, respectively. It also stood out for its high PC content (236.9 mg gallic acid $100 \mathrm{~g}^{-1}$ pulp). This genotype was selected as the second-best hybrid for fresh consumption but placed in the first position regarding processing.

The genotype RVCS11 was considered to be the third-best hybrid for fresh consumption and second for processing, standing out for its high SS content (10.14 Brix). RVCS09 was in the fourth position for both selection types, standing out for its PC content ( $215.12 \mathrm{mg}$ gallic acid $100 \mathrm{~g}^{-1}$ pulp) and having dual aptitude, as it presented desirable traits for both fresh consumption and processing.

\subsection{Principal Component and Hierarchical Cluster Analysis}

The principal component analysis (PCA) showed that the first two components accounted for $48.58 \%$ of the total variation (Figure 5). In accordance with the selection index, traits that were related to yield contributed the most to the divergence between genotypes. Moreover, the proximity between vectors confirms the high correlation found between them. The scatter plot split the hybrids into two groups (Figure 5). Hybrids RVCS10, RVCS04, and RVCS09 were more isolated when compared to the others, as they presented high values for agronomic traits.

Ward's hierarchical cluster method also split the hybrids into two groups (Figure 6), in accordance with the groups that formed by PCA. The 45 hybrids of the first group were allocated due to their high values for yield traits, also showing the highest values of SS/TA ratio, AA, and ANT. In the second group, which formed by 149 hybrids, the main traits included the highest values for TP, TA, and PC. Additionally, most of the hybrids selected by the Mulamba and Mock [27] index remained in Group I, including the four best-selected hybrids, both for fresh consumption and processing. 

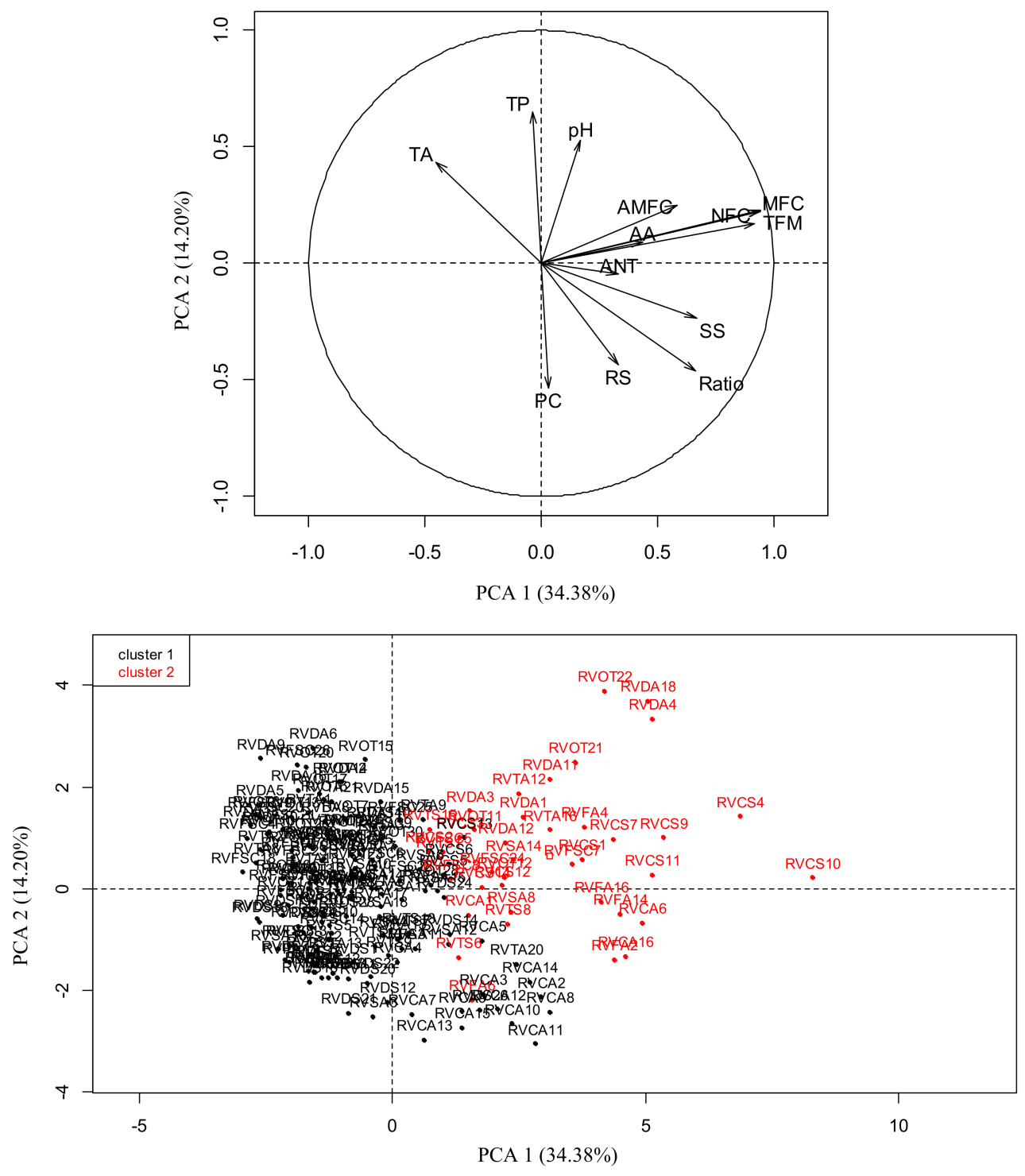

Figure 5. Principal component analysis between agronomic, physicochemical, and bioactive compound traits obtained from different Fragaria $\times$ ananassa Duchesne ex Rozierhybrids. NCF: Number of Commercial Fruits (fruits/plant), AMCF: Average Mass of Commercial Fruits (g/fruit), MCF: Mass of Commercial Fruits (g/plant1), TFM: Total Fruit Mass (g/plant), SS: Soluble Solids (Brix), TA: Titratable acidity (g citric acid $100 \mathrm{~g}^{-1}$ pulp), SS/TA Ratio: Soluble Solids/Titratable Acidity, RS: Reducing Sugar (\%), PC: Phenolic Compounds (mg galic acid $100 \mathrm{~g}^{-1}$ pulp), TP: Total Pectin (g total pectin $100 \mathrm{~g}^{-1}$ pulp), AA: Ascorbic Acid (mg ascorbic acid $100 \mathrm{~g}^{-1}$ pulp) and ANT: Anthocyanins (mg pelargonidin-3-glycoside $100 \mathrm{~g}^{-1}$ pulp). 


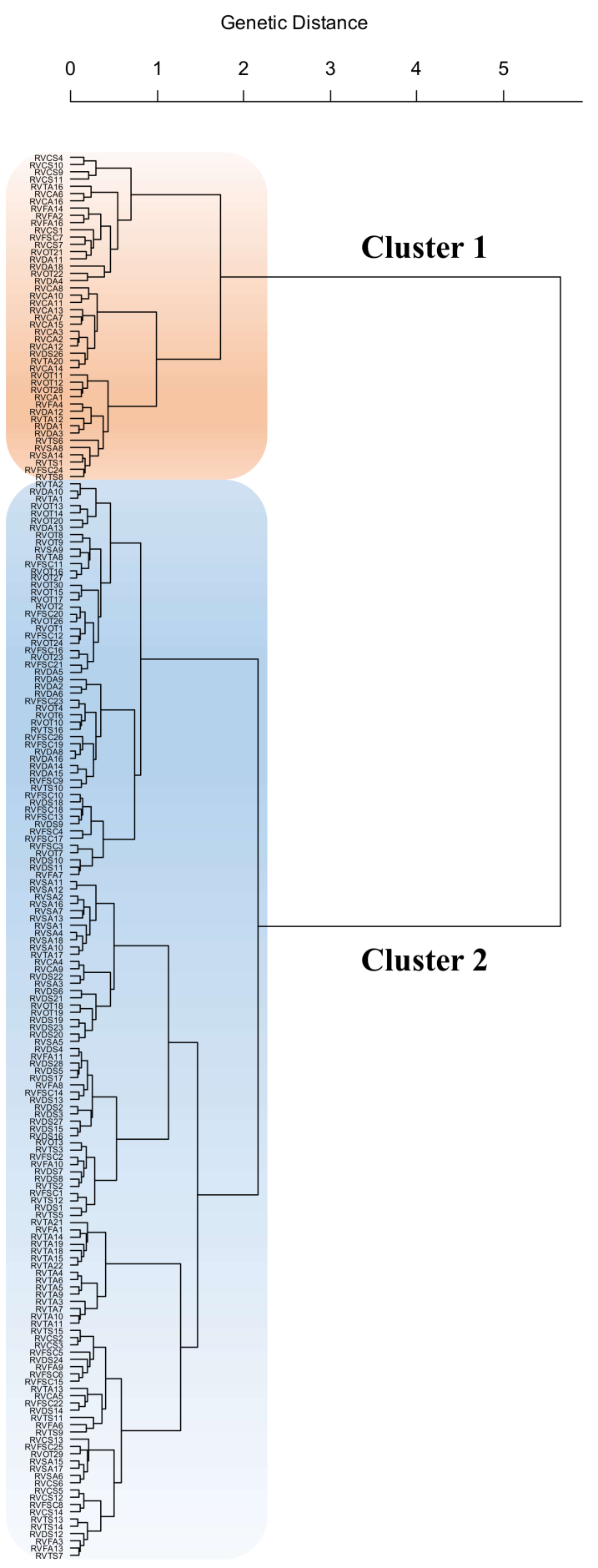

Figure 6. Ward's hierarchical cluster analysis based on the standardized mean Euclidean distance for agronomic, physicochemical, and bioactive compound traits that were obtained from different Fragaria $\times$ ananassa Duschesne ex Rozier hybrids.

\section{Discussion}

The main objective of this research was to assess and select strawberry genotypes that were obtained from intraspecific crossings, using multivariate analysis based on yield and physicochemical traits for fresh market and processing. High variability was observed among the assessed hybrids, with AMCF being the only trait that did not significantly differ between hybrids. These results are 
different from those that were found by Galvão et al. [12] and Vieira et al. [11], who assessed strawberry hybrids and found significant differences for all of the traits related to yield. No differences were found for soluble solids, titratable acidity, $\mathrm{pH}$, and anthocyanins. In contrast, the physicochemical attributes differed significantly between the hybrids that were assessed by Vieira et al. [30] and Camargo et al. [31].

It seems that the different results found among these studies are due to the genetic divergence present among cultivars and the octoploid nature of strawberry plants [32], which confers a high variability to hybrids, as it increases the number of allelic combinations that are available for selection. Genetic progress in a breeding program is directly proportional to the available genetic variability. Thus, the selection of the most divergent parents allows for individuals to possess superior genes in a segregating population. This variability can be observed when comparing the means of hybrids in relation to the controls and the occurrence of outliers within populations (Figures 1-3). These results highlight the different genotypic constitutions for each hybrid, which makes it easier to select new cultivars with good traits of economic interest [33].

Yield traits NCF, MCF, AMCF, and TFM showed high correlations with each other (Figure 4), which was already expected, as commercial fruits are big. Thus, the higher the weight is, the higher the values of TFM and AMCF [30]. However, yield traits showed no correlation with physicochemical attributes and bioactive compounds, except for SS/TA ratio and SS, thus hindering the selection process for fresh market and processing.

Yield traits also presented the highest heritability values (Table 2), corroborating the results of Vieira et al. [11,30], who assessed strawberry hybrids and found values above 80\% for NCF and TFM. In contrast, the authors found heritability below 60\% for SS/TA ratio and TP and higher values for SS (60.17 and 67\%, respectively). Similarly, Mishra et al. [34] studied the genetic variability and heritability of strawberry hybrids in Turkey and found a high heritability for SS (93.73\%). However, the difference between heritability levels is due to the different sites used for each assaywhen considering that the expression of a given trait is dependent on the genetic constitution, the environment in which the plant is grown, and the interaction between these two factors.

In plant selection, it is necessary to have information regarding quantitative genetics in the studied population. Thus, knowledge of heritability estimates, genetic correlation coefficients, estimates of expected gain from selection, and implications of the genetic and environmental effects on these estimates are essential for developing a breeding program. The high heritability indicates that the environment has little influence on the trait, which provides great chances for its improvement through selection [35]. However, the estimation of heritability alone is not sufficient to estimate the expected gain in the next generation, being recommended to consider it in conjunction with the estimation of genetic advancement to predict the effect of selection [36-38].

In some cases, broad-sense heritability is of little relevance to breeders, while narrow-sense heritability is more important. The effect of selection depends on the magnitude of the additive genetic variance and not on the total genetic variance [39].However, in vegetative propagation crops, additive and non-additive gene actions are transferred to the progeny and fixed by cloning, so broad-sense $h^{2}$ is also very important [40]. The estimated $\mathrm{h}^{2}$ values were moderately high, allowing for inferring that there was a significant contribution of non-additive genetic effects to the total genetic variance. These non-additive components can be dominance or epistasis [41].

Genetic gain for a given trait is the parameter that expresses the advance of the next generation in relation to the original population, due the selection made [42]. The yield traits showed the highest values of genetic gain, mainly for Total Fruit Mass (172.19\%), Mass of Commercial Fruit (190.82\%), and Number of Commercial Fruits (166.69\%). These traits have complex genetic inheritance, in which several genes with a quantitative effect are responsible for the manifestation of these factors. They are genes of dominant effect and are epistemic of high heritability, which explains the genetic gains of high magnitude that were obtained in the present research. Post-harvest characteristics are highly influenced by the environment, which explains the lower selection gain observed. 
When considering the high variability present in hybrids and low correlations between yield and postharvest traits, the use of methods that allow for the selection of multiple traits is a promising strategy to estimate the genetic advance and choose more balanced materials. The Mulamba and Mock [27] index showed that traits related to yield, which had high heritability, presented high gains, indicating a high reliability during the selection process. However, different gains between the selections for fresh consumption and processing show that the assignment of different economic weights can result in different groups of hybrids, according to the priorities established by the breeder. Simultaneous selection by indices identifies more balanced hybrids, mainly when a high number of traits are assessed [43], as they may be positively or negatively correlated to each other [34].

The choice of genotypes by the Mulamba and Mock [27] selection index showed that the crossing between 'Camarosa' and 'Sweet Charlie' resulted in the best hybrids for fresh consumption and processing. It is different from that observed by Galvão et al. [12], who obtained the best crossings between cultivars Camarosa and Aromas. However, the authors used no selection indices to choose the best materials, and hybrid development was performed under other Brazilian edaphoclimatic conditions. The highest number of hybrids was obtained between crossings that had 'Camarosa' as a female parent or 'Aromas' as a male parent. However, hybrids in which 'Camarosa' was the female parent are among those that presented the highest values for yield traits, being higher than the values that were found in hybrids selected by Galvão et al. [12], who also found 'Camarosa' as a female parent. The hybrid RVCS10, resulting from 'Camarosa' $\times$ 'Sweet Charlie', presented the highest value for SS/TA ratio (23.91), being higher than that found by Camargo et al. [31], who reported a value of 11.3 for the best hybrid from the crossing between these two parents.

The cultivar Camarosa is known for its high yield and large, firm, and tasty fruits [44]. Therefore, the superiority of hybrids regarding yield traits when 'Camarosa' was one of the parents is due to the presence of a high number of favorable alleles in this cultivar, which makes it a promising parent for strawberry breeding programs $[44,45]$. Currently, 'Camarosa' has been the most planted cultivar in the world, being a market leader for over twenty years [46,47], but it has sensitivity to photoperiod (short-day) and susceptibility to main diseases $[45,48,49]$. Thus, new crossings are required to generate hybrids with the agronomic and postharvest quality of 'Camarosa', but that have other levels of resistance to pests and diseases and different responses to temperature and photoperiod. The best hybrids identified using the Mulamba and Mock [27] selection index remained in the same group that was obtained by Ward's hierarchical method, as well as in the same group obtained by the principal component analysis, although this component onlyexplained $48.58 \%$ of the total variation (Figure 6 ).

Multivariate analyzes were useful for showing the diversity among the 194 genotypes, based on the traits evaluated, by the formation of clusters and PCA. In addition, the selection of genotypes by the Mulamba and Mock index, which was in agreement with the other methodologies, enabled the identification of hybrids with a better balance for the set of variables. This will make it possible to identify cultivars, from 28 selected genotypes, in experiments that were evaluated with more repetition and in more environmental conditions. On the other hand, knowledge of genetic diversity will make it possible to choose parents for inter- and intra-group crossings according to the breeding strategy adopted.

\section{Conclusions}

The multivariate analysis using different tools to access the variability present among hybrids allowed for a more complete and accurate description of genotypes, compiling information for guidance in the more assertive choice of better and more balanced hybrids, which could be released or used in strawberry breeding programs. It is recommended that hybrids be considered as superior to be assessed over different years and sites for studies of adaptability, stability, and sensoric perception of the consumer. 
Author Contributions: J.T.V.d.R., K.H.M. and A.R.Z. conceived the research idea. E.B., A.F.P.M., M.B.S., G.C.G.S. and J.G.M.M. helped to collect the data. L.S.A.G., S.R.R. and K.Y. analyzed the data and wrote the paper. All authors have read and agreed to the published version of the manuscript.

Funding: Financial resource made available via PRONEX, CNPq / Araucária Foundation.

Acknowledgments: The authors are grateful for $\mathrm{CNPq}$ and Araucária Foundation for the resource made available for the execution, CAPES for making the Master's scholarship available and the Midwest State University in Brazil for the infrastructure.

Conflicts of Interest: The authors declare no conflict of interest.

\section{References}

1. Whitaker, V.M.; Hasing, T.; Chandler, C.K.; Plotto, A.; Baldwin, E. Historical trends in strawberry fruit quality revealed by a trial of university of Florida cultivars and advanced selections. Horts 2011, 46, 553-557. [CrossRef]

2. FAO. FAOSTAT_Food and Agriculture Organization Corporate Statistical Database. FAO Online Database. Available online: http://www.fao.org/faostat/en/\#data (accessed on 5 February 2019).

3. Chandler, C.K.; Folta, K.; Dale, A.; Whitaker, V.M.; Herrington, M. Strawberry. In Fruit Breeding; Badenes, M.L., Byrne, D.H., Eds.; Springer US: Boston, MA, USA, 2012; pp. 305-325, ISBN 978-1-4419-0762-2.

4. Faedi, W.; Baruzzi, G. References. Strawberry breeding. In Strawberry: Growth, Development and Diseases; Husaini, A., Nari, D., Eds.; CABI: Wallingford, UK, 2016; pp. 26-37, ISBN 978-1-78064-663-3.

5. Giampieri, F.; Tulipani, S.; Alvarez-Suarez, J.M.; Quiles, J.L.; Mezzetti, B.; Battino, M. The strawberry: Composition, nutritional quality, and impact on human health. Nutrition 2012, 28, 9-19. [CrossRef] [PubMed]

6. Diamanti, J.; Capocasa, F.; Denoyes, B.; Petit, A.; Chartier, P.; Faedi, W.; Maltoni, M.L.; Battino, M.; Mezzetti, B. Standardized method for evaluation of strawberry (Fragaria $\times$ ananassa Duch.) germplasm collections as a genetic resource for fruit nutritional compounds. J. Food Compos. Anal. 2012, 28, 170-178. [CrossRef]

7. Padula, M.C.; Lepore, L.; Milella, L.; Ovesna, J.; Malafronte, N.; Martelli, G.; de Tommasi, N. Cultivar based selection and genetic analysis of strawberry fruits with high levels of health promoting compounds. Food Chem. 2013, 140, 639-646. [CrossRef]

8. Kim, S.K.; Kim, D.S.; Kim, D.Y.; Chun, C. Variation of bioactive compounds content of 14 oriental strawberry cultivars. Food Chem. 2015, 184, 196-202. [CrossRef]

9. Fagherazzi, A.F.; Grimaldi, F.; Kretzschmar, A.A.; Molina, A.R.; Gonçalves, M.A.; Antunes, L.E.C.; Baruzzi, G.; Rufato, L. Strawberry production progress in Brazil. Acta Hortic. 2017, 937-940. [CrossRef]

10. Zeist, A.R.; de Resende, J.T.V. Strawberry breeding in Brazil: Current momentum and perspectives. Hortic. Bras. 2019, 37, 7-16. [CrossRef]

11. Vieira, S.D.; de Souza, D.C.; Martins, I.A.; Ribeiro, G.H.M.R.; Resende, L.V.; Ferraz, A.K.L.; Galvão, A.G.; de Resende, J.T.V. Selection of experimental strawberry (Fragaria $\times$ ananassa) hybrids based on selection indices. Genet. Mol. Res. 2017, 16. [CrossRef]

12. Galvão, A.G.; Resende, L.V.; Maluf, W.R.; Resende, J.T.V.; Ferraz, A.K.L.; Marodin, J.C. Breeding new improved clones for strawberry production in Brazil. Acta Sci. Agron. 2017, 39, 149. [CrossRef]

13. Wrege, M.S.; Steinmetz, S.; Reisser Junior, C.; Almeida, I.R. Atlas climático da Região Sul do Brasil: Estados do Paraná, Santa Catarina e Rio Grande do Sul; Embrapa Clima Temperado: Pelotas, Brazil; Embrapa Florestas: Colombo, Brazil, 2012; p. 333.

14. Youssef, K.; de Oliveira, A.G.; Tischer, C.A.; Hussain, I.; Roberto, S.R. Synergistic effect of a novel chitosan/silica nanocomposites-Based formulation against gray mold of table grapes and its possible mode of action. Int. J. Biol. Macromol. 2019, 141, 247-258. [CrossRef]

15. IAL (Instituto Adolfo Lutz). Ministério da Saúde. Agência Nacional de Vigilância Sanitária. Métodos físico-químicos para análise de alimentos; Ministério da Saúde: Brasilia, Brazil, 2005.

16. Bucić-Kojić, A.; Planinić, M.; Tomas, S.; Bilić, M.; Velić, D. Study of solid-Liquid extraction kinetics of total polyphenols from grape seeds. J. Food Eng. 2007, 81, 236-242. [CrossRef]

17. McCready, R.M.; McComb, E.A. Extraction and Determination of Total Pectic Materials in Fruits. Anal. Chem. 1952, 24, 1986-1988. [CrossRef]

18. Bitter, T.; Muir, H.M. A modified uronic acid carbazole reaction. Anal. Biochem. 1962, 4, 330-334. [CrossRef] 
19. AOAC-Association of Official Analytical Chemists. Official Methods of Analysis of AOAC International; AOAC: Gaithersburg, MD, USA, 1984.

20. Youssef, K.; Hussien, A. Electrolysed water and salt solutions can reduce green and blue molds while maintain the quality properties of 'Valencia' late oranges. Postharvest Biol. Technol. 2020, 159, 111025. [CrossRef]

21. Giusti, M.M.; Wrolstad, R.E. Characterization and measurement of anthocyanins by UV-Visible spectroscopy. Cur. Prot. Food Anal. Chem. 2001, F1.2.1-F1.2.13. [CrossRef]

22. Cordeiro, E.C.N.; de Resende, J.T.V.; Córdova, K.R.V.; Nascimento, D.A.; SagginJúnior, O.J.; Zeist, A.R.; Favaro, R. Arbuscularmycorrhizal fungi action on the quality of strawberry fruits. Hortic. Bras. 2019, 37, 437-444. [CrossRef]

23. Mendiburu, F. Agricolae: Statistical Procedures for Agricultural Research. R Package Version 1.3-1.2014; R Project: Vienna, Austria, 2014.

24. Sou, T.; Nagashima, A. RcmdrPlugin.KMggplot2: R Commander Plug-in for Data Visualization with 'ggplot2'; R Project: Vienna, Austria, 2018.

25. Wei, T.; Simko, V.; Levy, M.; Xie, Y.; Jin, Y.; Zemla, J. Package 'corrplot'. Statistician 2017, 56, 316-324.

26. Cruz, C.D. Genes Software-Extended and integrated withthe R, MatlabandSelegen. Acta Sci. Agron. 2016, 38, 547. [CrossRef]

27. Mulamba, N.N.; Mock, J.J. Improvement of yield potential of the Eto Blanco maize (Zea mays L.) population by breeding for plant traits. Egypt. J. Genet. Cytol. 1987, 7, 40-51.

28. Barth, E. Aptidão de híbridos experimentais de morangueiro obtidos a partir de cruzamentos intraespecíficos. Master's. Thesis, Universidade Estadual do Centro-Oeste, Guarapuava, Brazil, 2017; p. 91.

29. Husson, F.; Josse, J.; Le, S.; Mazet, J. FactoMineR: Multivariate Exploratory Data Analysis and Data Mining with R, Version 1.42; R Project: Vienna, Austria, 2019.

30. Vieira, S.D.; Araujo, A.L.R.; Souza, D.C.; Resende, L.V.; Leite, M.E.; Resende, J.T.V. Heritability and combining ability studies in strawberry population. J. Agric. Sci. 2019, 11, 457. [CrossRef]

31. Camargo, L.K.P.; de Resende, J.T.V.; Camargo, C.K.; Kurchaidt, S.M.; Resende, N.C.V.; Botelho, R.V. Post-Harvest characterization of strawberry hybrids obtained from the crossing between commercial cultivars. Rev. Bras. Frutic. 2018, 40,1-4. [CrossRef]

32. Morales, R.G.F.; Resende, J.T.V.; Faria, M.V.; Andrade, M.C.; Resende, L.V.; Delatorre, C.A.; da Silva, P.R. Genetic similarity among strawberry cultivars assessed by RAPD and ISSR markers. Sci. Agric. (Piracicaba Braz.) 2011, 68, 665-670. [CrossRef]

33. Nunes, C.F.; Ferreira, J.L.; Generoso, A.L.; Carvalho, M.S.D.; Pasqual, M.; de Cançado, G.M.A. The genetic diversity of strawberry (Fragaria $\times$ ananassa Duch.) hybrids based on ISSR markers. Acta Sci. Agron. 2013, 35, 443-452. [CrossRef]

34. Mishra, P.K.; Ram, R.B.; Kumar, N. Genetic variability, heritability, and genetic advance in strawberry (Fragaria $\times$ ananassa Duch.). Turk. J. Agric. For. 2012, 39, 451-458. [CrossRef]

35. Kumar, R.; Kumar, S.; Singh, A.K. Genetic variability and diversity studies in snapdragon (Antirrhinum majus) under tarai conditions of Uttarakhand. Indian J. Agric. Sci. 2012, 82, 535-537.

36. Singh, A.; Singh, B.K.; Deka, B.C.; Sanwal, S.K.; Patel, R.K.; Verma, M.R. The genetic variability, inheritance and inter-relationships of ascorbic acid, $\beta$-carotene, phenol and anthocyanin content in strawberry (Fragaria $\times$ ananassa Duch.). Sci. Hortic. 2011, 129, 86-90. [CrossRef]

37. Dhivya, R.; Amalabalu, P.; Pushpa, R.; Kavithamani, D. Variability, heritability and genetic advance in upland cotton (Gossypium hirsutum L.). Afr. J. Plant Sci. 2014, 8, 1-5.

38. Ogunniyan, D.J.; Olakojo, S.A. Genetic variation, heritability, genetic advance and agronomic character association of yellow elite inbred lines of maize (Zea mays L.). Niger. J. Genet. 2014, 28, 24-28. [CrossRef]

39. Griffiths, A.J.; Gelbarth, W.M.; Lewontin, R.C.; Miller, J.H. Modern Genetic Analysis: Integrating Genes and Genomes, 2nd ed.; W. H. Freemann: New York, NY, USA, 2002; p. 736.

40. Acquaah, G. Principles of Plant Breeding and Genetics; Brackwell Publishing: Malden, MA, USA, 2007.

41. Ramalho, M.A.P.; Carvalho, B.L.; Nunes, J.A.R. Perspectives for the use of quantitative genetics in brreding of autogamous plants. ISRN Genet. 2013. [CrossRef]

42. Cruz, C.D. Princípios de Genética Quantitativa, 1st ed.; Universidade Federal de Viçosa: Viçosa, Brazil, 2010; p. 394. 
43. Santos, I.G.d.; Cruz, C.D.; Nascimento, M.; Rosado, R.D.S.; Ferreira, R.d.P. Direct, indirect and simultaneous selection as strategies for alfalfa breeding on forage yield and nutritive value. Pesqui. Agropecu. Trop. 2018, 48, 178-189. [CrossRef]

44. Gabriel, A.; de Resende, J.T.; Zeist, A.R.; Resende, L.V.; Resende, N.C.; Zeist, R.A. Phenotypic stability of strawberry cultivars based on physicochemical traits of fruits. Hortic. Bras. 2019, 37, 75-81. [CrossRef]

45. Zeist, A.R.; de Resende, J.T.; Lima Filho, R.B.; Gabriel, A.; Henschel, J.M.; da Silva, I.F. Phenology and agronomic components of first and second-Cycle strawberry. Hortic. Bras. 2019, 37, 29-34. [CrossRef]

46. Edger, P.P.; Poorten, T.J.; VanBuren, R.; Hardigan, M.A.; Colle, M.; McKain, M.R.; Smith, R.D.; Teresi, S.J.; Nelson, A.D.L.; Wai, C.M.; et al. Origin and evolution of the octoploid strawberry genome. Nat. Gene 2019, 51, 541-547. [CrossRef] [PubMed]

47. Samtani, J.B.; Rom, C.R.; Friedrich, H.; Fennimore, S.A.; Finn, C.E.; Petran, A.; Wallace, R.W.; Pritts, M.P.; Fernandez, G.; Chase, C.A.; et al. The status and future of the strawberry industry in the UnitedStates. Hortte 2019, 29, 11-24. [CrossRef]

48. Fang, X.; Phillips, D.; Verheyen, G.; Li, H.; Sivasithamparam, K.; Barbetti, M.J. Yields and resistance of strawberry cultivars to crown and root diseases in the field, and cultivar responses to pathogens under controlled environment conditions. Phytopathol. Mediterr. 2012, 51, 69-84.

49. Forcelini, B.B.; Gonçalves, F.P.; Peres, N.A. Effect of inoculum concentration and interrupted wetness duration on the development of anthracnose fruit rot of strawberry. Plant Dis. 2017, 101, 372-377. [CrossRef]

(C) 2020 by the authors. Licensee MDPI, Basel, Switzerland. This article is an open access article distributed under the terms and conditions of the Creative Commons Attribution (CC BY) license (http://creativecommons.org/licenses/by/4.0/). 